УДК 663.221/253.34:613.292

\title{
ФЕНОЛЬНЫЕ КОМПОНЕНТЫ ВИНОГРАДА СОРТА КАБЕРНЕ-СОВИНЬОН ВИНОДЕЛЬЧЕСКИХ ХОЗЯЙСТВ КРЫМА
}

\author{
() Г.П. Зайцев, В.Е. Мосолкова, Ю.В. Гришин, И.В. Черноусова", Ю.А. Огай, А.М. Авидзба \\ Национальный научно-исследовательский институт винограда и вина \\ «Магарач», ул. Кирова, 31, Ялта, Республика Крым, 298600 (Россия), e-mail: \\ chernblack@mail.ru
}

\begin{abstract}
Полифенольные соединения винограда, проявляющие оздоровительное воздействие на организм человека, были идентифицированы в составе водно-спиртовых экстрактов выжимки из винограда сорта Каберне-Совиньон методом ВЭЖХ. В выжимке винограда данного сорта из различных зон произрастания винограда Крыма обнаружен весь спектр биологически активных веществ полифенолов винограда: антоцианы, флавонолы, флаван-3-олы, оксикоричная и оксибензойные кислоты, стильбены, процианидины и продукты их конденсации. Суммарное содержание антоцианов, обусловливающих красную окраску продуктов переработки винограда, находится в пределах 6,7-8,9 г/кг сухого веса, сумма флаван-3-олов, процианидинов - 101,1-125,3 г/кг сухого веса и составляет более $90 \%$ общей суммы полифенолов, содержащихся в выжимке. Проведено сопоставление состава полифенолов винограда сорта Каберне-Совиньон из разных мест произрастания Крыма. Показано, что содержание полифенолов в выжимке зависит от зоны произрастания этого сорта винограда.
\end{abstract}

Ключевые слова: виноград, Vitis vinifera, полифенольные соединения винограда, выжимка винограда, ВЭЖХ.

Статья выполнена при финансовой поддержке Минобрнауки РФ. Уникальный идентификатор ПНИ RFMEFI60414Х0077 при подписании Соглашения №14.604.21.0077.

\section{Введение}

Одними из богатейших источников полифенолов являются ягоды винограда культурного (Vitis vinifera) и продукты их переработки. Современный интерес к продуктам из ягод винограда основан на многочисленных экспериментальных данных об их биологическом действии [1-7]. Фенольные соединения винограда и продуктов из винограда могут быть условно распределены на 2 группы: фенолокислоты, их производные и флавоноиды. Флавоноиды включают преимущественно такие соединения, как катехин, эпикатехин и их полимерные соединения, кверцетин и его производные и антоцианы.

Антоциановые пигменты винограда представляют собой гликозиды цианидина, дельфинидина, пеонидина, петунидина и мальвидина $[1,8]$. Антоцианы обладают обширным спектром биологической актив-

Зайцев Георгий Павлович - ведущий инженер, e-mail: gorg-83@mail.ru

Мосолкова Виктория Евгеньевна - ведущий инженер, e-mail: enoant@yandex.ru

Гришин Юрий Владимирович - младший научный сотрудник, e-mail: grishin.iurij2010@mail.ru Черноусова Инна Владимировна - ведущий инженер, кандидат технических наук, e-mail: chernblack@ mail.ru Огай Юрий Алексеевич - заместитель директора по инновационной и инвестиционной деятельности, кандидат технических наук, старший научный сотрудник, e-mail: enoant@yandex.ru

Авидзба Анатолий Мканович - директор, доктор сельскохозяйственных наук, академик, e-mail: magarach@rambler.ru ности для организма человека, среди которого особенно выделяется способность увеличивать эластичность кровеносных сосудов и улучшать остроту зрения [9, 10].

Флаван-3-олы (катехины) являются структурными элементами процианидинов. Сумма катехинов и процианидинов составляет более $90 \%$ общей суммы фенолов, содержащихся в винограде или вине $[11,12]$. Катехины и процианидины являются мощнейшими антиоксидантами, по активности превосходящими витамин С и Е [13]. Неполимеризованные флаван-3-олы проявляют ряд эффек-

\footnotetext{
* Автор, с которым следует вести переписку.
} 
тов, обусловливающих оздоровительное воздействие полифенолов винограда. К примеру, они способны ингибировать биосинтез простагландинов, катализируемый циклооксигеназой-2, что приводит к подавлению воспалительных процессов в организме [13]. Некоторые катехины, например (-)-эпикатехин и (-)-эпигаллокатехингаллат, способны индуцировать апоптоз опухолевых клеток [14]. Олигомерные процианидины, проникая в кровь, замедляют окисление низковязких липопротеидов плазмы крови, предупреждая сердечно-сосудистые расстройства [15], и снижают содержание холестерина, препятствуя развитию атеросклероза [16]. Полимерные процианидины практически не проникают в кровь, однако благодаря выраженным дубильным свойствам они способствуют нормализации микрофлоры кишечника [17].

Флавонолы представлены преимущественно кверцетином и его гликозидами. Флавонолы влияют на эластичность и проницаемость капиллярных кровеносных сосудов и улучшают коронарное кровообращение [18]. Среди полифенолов винограда, не являющихся флавоноидами, выделяют оксикоричные кислоты: пара-кумаровая кислота, кофейная кислота; производные бензойной кислоты - галловая кислота, а также стильбеновое производное - транс-ресвератрол [19]. Фенолокислоты - широко распространенные в мире растительных соединений органические кислоты, обладающие высокой антиоксидантной активностью. Биологическая активность этих кислот на организм человека проявляется в снижении уровня холестерина в крови и даже в ингибировании ВИЧ-инфекции [20]. Транс-ресвератрол является веществом с высокой биологической активностью. Он вступает во взаимодействие с эстрогенными рецепторами, проявляя ряд эффектов, в том числе оказывает мощное влияние на состояние сердечно-сосудистой системы [19]. Активирует механизмы клеточной регуляции, приводящие к естественному отмиранию «сбойных» клеток (апоптозу) и, таким образом, проявляет противораковое действие [21]. Включение продуктов, содержащих транс-ресвератрол, в пищевой рацион человека является эффективным способом профилактики заболеваний раком и нарушениями сердечно-сосудистой системы.

Полифенолы, в том числе флавоноиды, хотя и являются жизненно важным ресурсом, самостоятельно не синтезируются в организме человека и поступают в него исключительно с растительной пищей, однако биологическая доступность полифенолов для организма человека крайне низка вследствие того, что они слаборастворимы в воде [6]. Лишь в очень незначительных количествах полифенолы усваиваются организмом человека при непосредственном употреблении ягод винограда в пищу. В биологически [22] легкодоступной форме и в достаточно высокой концентрации полифенолы могут применяться в составе виноградных пищевых концентратов, приготовленных по специальным технологиям. Например, формой практического применения полифенолов винограда Каберне-Совиньон является пищевой концентрат «ЭНОАНТ», изготовляемый из ягод широко распространенного в промышленных посадках Крыма винограда сорта Каберне-Совиньон [22-24]. Известно также, что наибольшая концентрация полифенолов сосредоточена в кожице и семенах ягод красных сортов винограда [1].

Цель настоящей работы - исследование состава и содержания фенольных компонентов выжимки винограда Каберне-Совиньон разных винодельческих районов Крыма как сырья для получения пищевых продуктов, содержащих полифенолы.

\section{Материалы и методы исследования}

Материалом для исследования послужили спиртовые экстракты выжимки винограда сорта КабернеСовиньон, собранных в винодельческих хозяйствах Крыма юго-западного региона, южного побережья и в районе Севастополя. Образцы винограда отбирали в сентябре-октябре 2014 г. период массового сбора винограда. Для приготовления спиртовых экстрактов использовали выжимку, полученную из виноградной ягоды путем предварительного отделения последней от гребней и отжима на корзиночном ручном прессе. Экстракцию проводили путем смешивания 700 г виноградной выжимки 350 мл 96\%-ного этанола и настаивания в течение 30 дней при комнатной температуре. По истечении срока настаивания выжимку отделяли от спиртового экстракта путем фильтрации. Влажность выжимки определяли по ГОСТ 28561 [25]. Содержание сухих веществ в образцах выжимок находилось в пределах 33,8-37,5\%.

Качественный и количественный состав полифенолов в спиртовых экстрактах выжимки винограда проводили методом ВЭЖХ с использованием хроматографической системы Agilent Technologies (модель $1100)$ с диодно-матричным детектором. Для разделения веществ использовали хроматографическую колонку Zorbax SB-C18 размером 2,1×150 мм, заполненную силикагелем с привитой октадецилсилильной фазой 
с размером частиц сорбента 3,5 мкм. Хроматографирование проводили в градиентном режиме. Состав элюента: раствор А - метанол, раствор В - 0,6\%-ный водный раствор трифторуксусной кислоты. Состав элюента в ходе хроматографирования изменялся по следующей схеме (по содержанию компонента В): 0 мин - 8\%; 08 мин - 8-38\%; 8-24 мин - 38-100\%; 24-30 мин -100\%. Скорость потока элюента - 0,25 мл/мин. Объем вводимой пробы - 1 мкл. Хроматограммы регистрировали при следующих длинах волн: 280 нм - для галловой кислоты, (+)-D-катехина, (-)-эпикатехина и процианидинов, 313 нм - для производных оксикоричных кислот, 371 нм - для кверцетина и 525 нм - для антоцианов. Идентификацию веществ производили путем сравнения их спектральных характеристик и времени удерживания с аналогичными характеристиками стандартов. Спектральные характеристики отдельных веществ получали с использованием данных литературы $[13,15,26]$.

Расчет количественного содержания индивидуальных компонентов производили с использованием калибровочных графиков зависимости площади пика от концентрации вещества, построенных по растворам индивидуальных веществ. Содержание антоцианов определяли в пересчете на хлорид мальвидин-3-Оглюкозида, содержание кафтаровой кислоты - в пересчете на кофейную кислоту, содержание полимерных и олигомерных процианидинов производили аналогично методу, описанному в работе [27], но в пересчете на (+)-D-катехин. Все определения осуществляли в трех повторностях. Для обеспечения однородности результатов содержания веществ рассчитали в мг/кг массы сухой выжимки.

В качестве стандартов использовали галловую кислоту, кофейную кислоту, (+)-D-катехин, хлорид мальвидин-3-О-глюкозида, кверцетин дигидрат, изокверцитрин (Fluka Chemie AG, Швейцария) и трансресвератрол, (-)-эпикатехин, сиреневую кислоту фирмы (Sigma-Aldrich, Швейцария).

Результаты исследований обрабатывали стандартными методами математической статистики [28].

\section{Результаты и их обсуждение}

В ходе исследования состава полифенолов в экстрактах выжимки винограда сорта Каберне-Совиньон были идентифицированы соединения следующих групп полифенолов: антоцианы; флаван-3-олы, олигомерные процианидины, флавонолы, оксикоричные и оксибензойные кислоты. Содержание идентифицированных фенольных соединений в образцах выжимки из различных винодельческих хозяйств Крыма представлено в таблице. Хроматограммы экстрактов выжимок при 280 и 525 нм приведены на рисунках 1 и 2.

Согласно данным таблицы, суммарное содержание антоцианов, обусловливающих красную окраску продуктам переработки винограда, находится в пределах 6700-8900 мг/кг сухого веса. Сумма флаван-3олов и процианидинов находится в пределах от 101087 до 125287 мг/ кг и составляет более 90\% общей суммы фенолов, содержащихся в винограде, что согласуется с литературными данными [11]. Идентифицированы полифенольные вещества, не являющиеся флавоноидами, к ним относятся фенолокислоты и транс-ресвератрол. Суммарное содержание данных компонентов составляет от 140-340 мг/кг. Флавонолы представлены кверцетином и его производным кверцетин-3-О-глюкозидом. В наших исследованиях содержание кверцетина и его гликозида в виноградной выжимке не превышает 350 мг/кг. По содержанию катехинов весомо лидируют выборки из юго-западного района и совхоза «Ливадия», южнобережного Крыма.

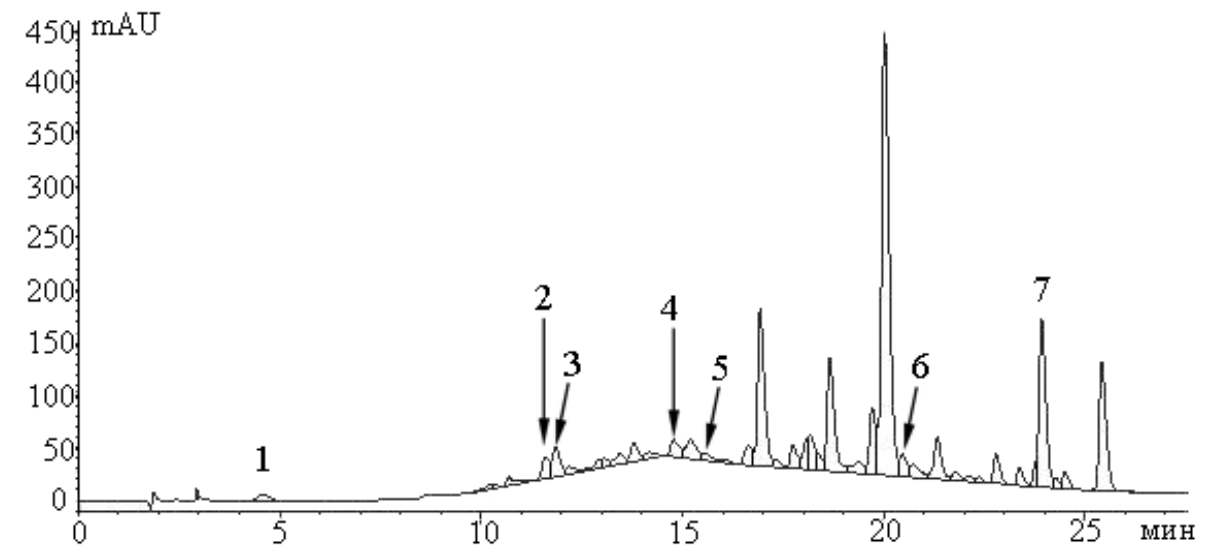

Рис. 1. Хроматограмма экстракта выжимки винограда сорта Каберне-Совиньон ГП Совхоз-завод им. П. Осипенко при 280 нм. 1 - галловая к-та, 2 - кафтаровая к-та, 3 - (+)-D-катехин, 4 - (-)-эпикатехин, 5 - сиреневая к-та, 6 - кверцетин-3-О-глюкозид, 7 - кверцетин 


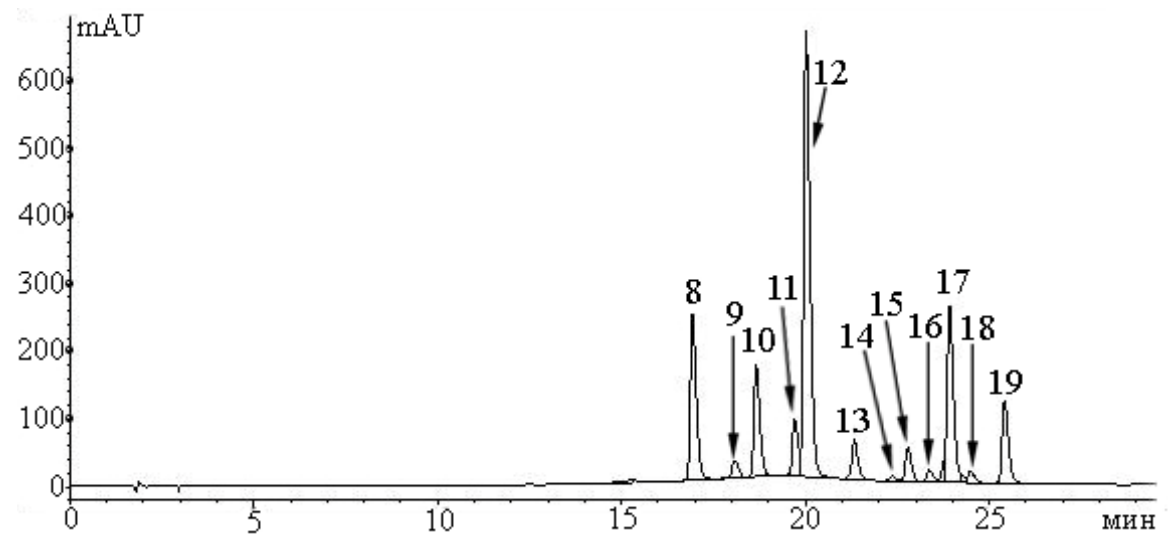

Рис. 2. Хроматограмма экстракта выжимки винограда сорта Каберне-Совиньон ГП Совхоз-завод им. П. Осипенко при 525 нм. 8 - дельфинидин-3-О-глюкозид, 9 - цианидин-3-О-глюкозид, 10 - петунидин-3-О-глюкозид, 11 - пеонидин-3-О-глюкозид, 12 - мальвидин-3-О-глюкозид, 13 - дельфинидин-3-О-ацетилглюкозид, 14 - цианидин-3-О-ацетилглюкозид, 15 - петунидин-3-Оацетилглюкозид, 16 - пеонидин-3-О-ацетилглюкозид, 17 - мальвидин-3-О-ацетилглюкозид, 18 - петунидин-3-О-кумароилглюкозид, 19 - мальвидин-3-О-кумароилглюкозид

Фенольные компоненты выжимки из винограда сорта Каберне-Совиньон (содержание в мг/кг сухой массы выжимки)

\begin{tabular}{|c|c|c|c|c|c|}
\hline \multirow[b]{2}{*}{ Фенольные компоненты } & \multirow{2}{*}{$\begin{array}{c}\text { Юго-западный } \\
\text { район Крыма } \\
\text { ГП } \\
\text { агрофирма } \\
\text { «Магарач» }\end{array}$} & \multicolumn{3}{|c|}{ Южное побережье Крыма } & \multirow{2}{*}{$\begin{array}{c}\text { Район } \\
\text { Севастополь } \\
\text { ГП Совхоз- } \\
\text { завод } \\
\text { им. П. Осипенко }\end{array}$} \\
\hline & & $\begin{array}{c}\text { Совхоз-завод } \\
\text { «Алушта» }\end{array}$ & $\begin{array}{c}\text { Совхоз-завод } \\
\text { «Гурзуф» }\end{array}$ & $\begin{array}{c}\text { Совхоз-завод } \\
\text { «Ливадия» }\end{array}$ & \\
\hline \multicolumn{6}{|c|}{ Aнтоцииань } \\
\hline Дельфинидин-3-О-глюкозид & 356 & 346 & 643 & 376 & 1187 \\
\hline Цианидин-3-О-глюкозид & 52 & 66 & 91 & 55 & 153 \\
\hline Петунидин-3-О-глюкозид & 346 & 359 & 558 & 347 & 795 \\
\hline Пеонидин-3-О-глюкозид & 262 & 300 & 310 & 371 & 416 \\
\hline Мальвидин-3-О-глюкозид & 3389 & 3213 & 3461 & 3493 & 3508 \\
\hline Дельфинидин-3-О-ацетилглюкозид & 116 & 124 & 183 & 108 & 300 \\
\hline Цианидин-3-О-ацетилглюкозид & 17 & 15 & 11 & 11 & 27 \\
\hline Петунидин-3-О-ацетилглюкозид & 139 & 122 & 167 & 101 & 242 \\
\hline Пеонидин-3-О-ацетилглюкозид & 55 & 36 & 47 & 39 & 89 \\
\hline Мальвидин-3-О-ацетилглюкозид & 2022 & 1560 & 1476 & 1402 & 1401 \\
\hline Петунидин-3-О-кумароилглюкозид & 72 & 39 & 54 & 50 & 84 \\
\hline Мальвидин -3-О-кумароилглюкозид & 944 & 511 & 515 & 718 & 666 \\
\hline \multicolumn{6}{|c|}{ Флавоноль } \\
\hline Кверцетин-3-О-глюкозид & 46 & 161 & 170 & 200 & 221 \\
\hline Кверцетин & 177 & 137 & 132 & 140 & 147 \\
\hline \multicolumn{6}{|c|}{ Флаван-3-ольы } \\
\hline (+)-D-Катехин & 2138 & 1501 & 1478 & 2574 & 1711 \\
\hline (-)-Эпикатехин & 1849 & 1086 & 1247 & 1803 & 921 \\
\hline \multicolumn{6}{|c|}{ Оксикоричнье кислотьл } \\
\hline Кафтаровая кислота & 9 & 67 & 45 & 79 & 173 \\
\hline \multicolumn{6}{|c|}{ Оксибензойнье кислотьл } \\
\hline Галловая кислота & 54 & 46 & 53 & 69 & 51 \\
\hline Сиреневая кислота & 62 & 63 & 26 & 53 & 17 \\
\hline \multicolumn{6}{|c|}{ Стильбень } \\
\hline Транс-ресвератрол & 28 & 9 & 19 & 54 & 92 \\
\hline \multicolumn{6}{|c|}{ Прочиианидины и продукты конденсации } \\
\hline Олигомерные процианидины & 6000 & 3600 & 4000 & 5900 & 5300 \\
\hline Полимерные процианидины & 115300 & 94900 & 94800 & 96600 & 106300 \\
\hline \multicolumn{6}{|c|}{ Интегральные показатели } \\
\hline Сумма полифенолов методом ВЭЖХ & 133400 & 108200 & 109400 & 114500 & 123700 \\
\hline
\end{tabular}


Антоциановый комплекс винограда, формирующий красный цвет продуктов переработки винограда, представлен моноглюкозидами мальвидина, пеонидина, петунидина, цианидина, дельфинидина. В выжимке винограда, произрастающего на южном побережье Крыма, к сроку уборки винограда накоплено антоцианов (на 9-24\%), процианидинов (на 14-23\%) меньше, чем в выжимке винограда, произрастающего в западной части Крымского полуострова, та же тенденция сохраняется для гликозидной формы кверцетина и кафтаровой кислоты. Результаты исследований подтверждают данные литературы [29] о зависимости формирования фенольного комплекса винограда от климатических и агротехнических условий его культивирования.

\section{Bыводы}

1. В выжимках из ягод винограда Каберне-Совиньон были идентифицированы фенольные соединения следующих групп: антоцианы, флавонолы, флаван-3-олы, оксикоричные кислоты, оксибензойные кислоты, процианидины и продукты конденсации.

2. Полученные данные дают возможность оценить качественный и количественный состав фенольных веществ винограда сорта Каберне-Совиньон. Содержание полифенолов в выжимке зависит от зоны произрастания этого сорта винограда. Из наиболее перспективных перечисленных винодельческих хозяйств Крыма - это юго-западный район Крыма и район города Севастополя, которые могут быть успешно использованы как сырьевая база для получения пищевых продуктов, содержащих полифенолы.

\section{Список литературы}

1. Загайко А.Л., Красильникова О.А., Кравченко А.Б., Волощенко М.В., Огай Ю.А., Соловьева Л.М., Мизин В.И., Богадельников И.В. Биологически активные вещества винограда и здоровье: монография. Харьков, 2012. $404 \mathrm{c}$.

2. Beecher G.R. Overviewofdietaryflavonoids: nomenclature, occurrenceandintake // J. Nutr. 2003. Vol. 133 , N10. Pp. 3248-3254.

3. Tsao R. Chemistry and biochemistry of dietary polyphenols // Nutrients. 2010. Pp. 1231-1246.

4. Hertog M.G., Sweetnam P.V., Fehily A.M., Elwood P.C., Kromhout d. Hertog M.C. Antioxidant flavonols and ischemic heart disease in a Welsh population of men: the Caerphilly Study // Am. J. Clin. Nutr. 1997. Vol. 65 b, N5. Pp. 1489-1494.

5. Pagano G., Castello G., Gallo M., Borriello J., Guida M. Complex mixture-associated hormesis and toxicity: the case of leather tanning industry // Dose Response. 2008. Vol. 6b, N4. Pp. 383-396.

6. Clifford M.N. Diet-derived phenols in plasma and tissues and their implications for health // Planta Med. 2004. Vol. 70, N12. Pp. 1103-1114.

7. Valls J., Milln S., Marti M.P., Borras E., Arola L. Advanced separation methods of food antocyanins, isoflavones and flavanols // J. Chromatogr A. 2009 .Vol. 1216, N43. Pp. 7143-7172.

8. Wang H., Race E.J., Strikhande A.J. Anthocyanin Transformation in Cabernet Sauvignon Wine during aging // J. Agric. Food Chem. 2003. Vol. 51. Pp. 7989-7994.

9. Del Rio D., Borges G., Crozier A. Berry flavonoids and phenolics. Bioavailability and evidence of protective effects // Br. J. Nutr. 2010. Vol. 3. Pp. 67-90.

10. Choi E.H., Park J.H., Kim M.K., Chun H.S. Alleviation of doxorubicin - induced toxicities by anthocyanin -rich bilberry (Vaccinium myrtillus L.) extract in rats and mice // Biofactors. 2010. Vol. 36, N4. Pp. 319-327.

11. Freitas V.A.P., Glories Y., Bourgeois G., Vitry C. Characterisation of Oligomeric and Polymeric Procyanidins from Grape Seeds by Liquid Secondary Ion Mass Spectrometry // Phytochemistry. 1998. Vol. 49, N5. Pp. 1435-1441.

12. Gachons C.P., Kennedy J.A. Direct Method for Determining Seed and Skin Proanthocyanidin Extraction into Red Wine // J. Agric. Food Chem. 2003. Vol. 51. Pp. 5877-5881.

13. Bagchi D., Bagchi M., Stohs S.J., Das D.K., Ray S.D., Kuszynski C.A., Joshi S.S., Pruess H.G. Free radicals and grape seed proanthocyanidn extract: importance in human health and disease prevention // Toxicology. 2000. Vol. 148. Pp. 187-197.

14. Ahmad N., Gupta S., Mukhtar H. Green tea polyphenol epigallocatechin-3-gallate differentially modulates nuclear factor $\mathrm{kB}$ in cancer cells versus normal cells // Archives of Biochemistry and Biophysics. 2000. Vol. 376. Pp. 338-346.

15. Bagchi D., Sen C.K., Ray S.D., Dipak K., Bagchi M., Preuss H.G., Vinson J.A. Molecular mechanisms of cardioprotection by a novel grape seed proanthocyanidin extract // Mutation Research. 2003. Vol. 523. Pp. 87-97.

16. Vinson J.A., Mandarano M.A., Shuta D.L., Bagchi M., Bagchi D. Beneficial effects of a novel IH636 grape seed proanthocyanidin extract and a niacin-bound chromium in a hamster aterosclerosis model // Molecular and Cellular Biochemistry. 2002. Vol. 240. Pp. 99-103.

17. Foo L.Y., Porter L.J. The phytochemistry of proanthocyanidin polymers // Phytochemistry. 1980. Vol. 19. Pp. 1747-1754.

18. Chen C.K., Pace-Asciak C.R. Vasorelaxing activity of resveratrol and quercetin in isolated rat aorta // Gen. Pharmacol. 1996. Vol. 27. Pp. 363-366.

19. Lin J.K., Tsai S.H. Chemoprevention of Cancer and Cardiovascular Disease by Resveratrol // Proc. Natl. Sci. Counc. ROC(B). 1999. Vol. 23, N3. Pp. 99-106.

20. King P.J., Ma G., Miao W., Jia Q., McDoughall B.R., Reinecke M.G., Cornell C., Kuan J., Kim T.R., Robinson Jr.W.E. Structure-activity relationships: analogues of the dicaffeoylquinic and dicaffeoyltartaric acids as potent inhibitors of human immunodeficiency virus type 1 integrase and replication // J. Med. Chem. 1999. Vol. 42. Pp. 497-509. 
21. Aggarwal B.B., Bhardwaj A., Aggarwal R.S., Seeram N.P., Shishodia S., Takada Y. Role of Resveratrol in Prevention and Therapy of Cancer: Preclinical and Clinical Studies // Anticancer Research. 2004. Vol. 24 (5120-A). Pp. 3-60.

22. Огай Ю.А., Алексеева Л.М., Сиказан О.М., Катрич Л.И. Полифенольные биологически активные компоненты пищевого концентрата «Эноант» // Проблемы, достижения и перспективы развития медико-биологических наук и практического здравоохранения: материалы конференции. Симферополь, 2005. Т. 141, ч. 1. С. 14-19.

23. Соляник Г.И., Тодор И.Н., Шпилевая С.И., Пясковская О.Н., Дасюкевич О.И. Использование «Эноанта» для коррекции токсических проявлений противоопухолевой терапии цисплатином в эксперименте // Проблемы, достижения и перспективы развития медико-биологических наук и практического здравоохранения. Симферополь, 2005. Т. 141, ч. 1. С. 60-67.

24. Банахевич Н.В., Олейниченко Г.П., Березецкая Н.М., Соляник Г.И. Использование «Эноанта» для коррекции анемий у онкологических больных (клинические исследования) // Проблемы, достижения и перспективы развития медико-биологических наук и практического здравоохранения. Симферополь, 2005. Т. 141, ч. 1. С. 68-71.

25. ГОСТ 28561-90. Продукты переработки плодов и овощей. Метод определения сухих веществ или влаги.

26. Woodring P.J., Edwards P.A., Chisholm M.G. HPLC determination of nonflavonoid phenols in vidal blanc wine using electrochemical detection // J. Agric. Food Chem. 1990. Vol. 38. Pp. 729-732.

27. Peng Z., Hayasaka Y., Iland P.G., Sefton M., Hoj P., Waters E.J. Quantitative Analysis of Polymeric Procyanidins (Tannins) from Grape (Vitis vinifera) Seeds by Reverse Phase High-Performance Liquid Chromatography // J. Agric. Food Chem. 2001. Vol. 49, N1. Pp. 26-31.

28. Лакин Г.Ф. Биометрия: учеб. пособие для биол. спец. вузов. М., 1990. 352 с.

29. Валуйко Г.Г. Технология виноградных вин. Симферополь, 2001. 624 с.

Поступило в редакцию 23 декабря 2014 2.

После переработки 27 апреля 2015 г.

Zaitsev G.P., Mosolkova V.E., Grishin Yu.V., Chernousova I.V., Ogai Yu.A., Avidzba A.M. PHENOLIC COMPOUNDS IN CABERNET-SAUVIGNON GRAPE VARIETY AT WINE-MAKING FARMS OF CRIMEA

«Magarach» National Research Institute for grape and wine, 31 Kirov Str, Yalta, Republic of Crimea, 298600 (Russia), e-mail: chernblack@mail.ru

Polyphenolic grape compounds, showing health-improving effect on the human's body, were identified in composition of aqueous-alcoholic extracts of Cabernet-Sauvignon grape variety pomace, using HPLC method. The grape pomace of the above variety was taken from different grape growing zones of Crimea. It contains all spectrum of biologically active grape polyphenols' substances: anthocyans, flavonols, flavan-3-ols, oxicynnamic and oxibenzoic acids, stilbenes, procyanidins and their condensation products. Total number of anthocyans, which cause red color of grape-processed products, is between 6,7$8,9 \mathrm{~g} / \mathrm{kg}$ dry weigh, total number of phlavon-3-ols, procyanidins is $101,1-125,3 \mathrm{~g} / \mathrm{kg}$ dry weigh. It exceeds $90 \%$ of total polyphenols, contained in the pomace. Cabernet-Sauvignion variety polyphenolic composition was compared in different grapegrowing places of Crimea. It shows that polyphenolic content in the pomace depends on grape-growning zone of the variety.

Keywords: grape, Vitis vinifera, grape polyphenolic compounds, grape pomace, HPLC.

\footnotetext{
* Corresponding author.
} 


\section{References}

1. Zagaiko A.L., Krasil'nikova O.A., Kravchenko A.B., Voloshchenko M.V., Ogai Iu.A., Solov'eva L.M., Mizin V.I., Bogadel'nikov I.V. Biologicheski aktivnye veshchestva vinograda $i$ zdorov'e: monografiia. [Biologically active substances of grapes and Health: Monograph]. Kharkiv, 2012. 404 c. (in Russ.).

2. Beecher G.R. J. Nutr., 2003, vol. 133, no. 10, pp. 3248-3254.

3. Tsao R. Nutrients, 2010, pp. 1231-1246.

4. Hertog M.G., Sweetnam P.V., Fehily A.M., Elwood P.C., Kromhout d. Hertog M.C. Am. J. Clin. Nutr., 1997, vol. 65b, no. 5, pp. 1489-1494.

5. Pagano G., Castello G., Gallo M., Borriello J., Guida M. Dose Response, 2008, vol. 6b, no. 4, pp. 383-396.

6. Clifford M.N. Planta Med., 2004, vol. 70, no. 12, pp. 1103-1114.

7. Valls J., Milln S., Marti M.P., Borras E., Arola L. J. Chromatogr A, 2009, vol. 1216, no. 43, pp. 7143-7172.

8. Wang H., Race E.J., Strikhande A.J. J. Agric. Food Chem., 2003, vol. 51, pp. 7989-7994.

9. Del Rio D., Borges G., Crozier A. Br. J. Nutr., 2010, vol. 3, pp. 67-90.

10. Choi E.H., Park J.H., Kim M.K., Chun H.S. Biofactors, 2010, vol. 36, no. 4, pp. 319-327.

11. Freitas V.A.P., Glories Y., Bourgeois G., Vitry C. Phytochemistry, 1998, vol. 49, no. 5, pp. 1435-1441.

12. Gachons C.P., Kennedy J.A. J. Agric. Food Chem., 2003, vol. 51, pp. 5877-5881.

13. Bagchi D., Bagchi M., Stohs S.J., Das D.K., Ray S.D., Kuszynski C.A., Joshi S.S., Pruess H.G. Toxicology, 2000, vol. 148, pp. 187-197.

14. Ahmad N., Gupta S., Mukhtar H. Archives of Biochemistry and Biophysics, 2000, vol. 376, pp. 338-346

15. Bagchi D., Sen C.K., Ray S.D., Dipak K., Bagchi M., Preuss H.G., Vinson J.A. Mutation Research, 2003, vol. 523, pp. 87-97.

16. Vinson J.A., Mandarano M.A., Shuta D.L., Bagchi M., Bagchi D. Molecular and Cellular Biochemistry, 2002 , vol. 240, pp. 99-103.

17. Foo L.Y., Porter L.J. Phytochemistry, 1980, vol. 19, pp. 1747-1754.

18. Chen C.K., Pace-Asciak C.R. Gen. Pharmacol., 1996, vol. 27, pp. 363-366.

19. Lin J.K., Tsai S.H. Proc. Natl. Sci. Counc. ROC(B), 1999, vol. 23, no. 3, pp. 99-106.

20. King P.J., Ma G., Miao W., Jia Q., McDoughall B.R., Reinecke M.G., Cornell C., Kuan J., Kim T.R., Robinson Jr.W.E. J. Med. Chem., 1999, vol. 42, pp. 497-509.

21. Aggarwal B.B., Bhardwaj A., Aggarwal R.S., Seeram N.P., Shishodia S., Takada Y. Anticancer Research, 2004 , vol. 24 (5120-A), pp. 3-60.

22. Ogai Iu.A., Alekseeva L.M., Sikazan O.M., Katrich L.I. Problemy, dostizheniia i perspektivy razvitiia medikobiologicheskikh nauk i prakticheskogo zdravookhraneniia: materialy konferentsii. [Problems, achievements and prospects of development of the life sciences and health care practice: conference materials]. Simferopol. 2005, vol. 141, part. 1, pp. 14-19. (in Russ.).

23. Solianik G.I., Todor I.N., Shpilevaia S.I., Piaskovskaia O.N., Dasiukevich O.I. Problemy, dostizheniia i perspektivy razvitiia mediko-biologicheskikh nauk $i$ prakticheskogo zdravookhraneniia: materialy konferentsii. [Problems, achievements and prospects of development of the life sciences and health care practice: conference materials]. Simferopol. 2005, vol. 141, part. 1, pp. 60-67. (in Russ.).

24. Banakhevich N.V., Oleinichenko G.P., Berezetskaia N.M., Solianik G.I. Problemy, dostizheniia i perspektivy razvitiia mediko-biologicheskikh nauk i prakticheskogo zdravookhraneniia: materialy konferentsii. [Problems, achievements and prospects of development of the life sciences and health care practice: conference materials]. Simferopol. 2005, vol. 141, part. 1, pp. 68-71. (in Russ.).

25. GOST 28561-90. Produkty pererabotki plodov i ovoshchei. Metod opredeleniia sukhikh veshchestv ili vlagi. [State Standard 28561-90. Products of fruits and vegetables. Method for determination of dry matter and moisture]. (in Russ.).

26. Woodring P.J., Edwards P.A., Chisholm M.G. J. Agric. Food Chem., 1990, vol. 38, pp. 729-732.

27. Peng Z., Hayasaka Y., Iland P.G., Sefton M., Hoj P., Waters E.J. J. Agric. Food Chem., 2001, vol. 49, no. 1, pp. $26-31$.

28. Lakin G.F. Biometriia. [Biometry]. Moscow, 1990, 352 p. (in Russ.).

29. Valuiko G.G. Tekhnologiia vinogradnykh vin. [The technology of grape wines]. Simferopol, 2001, 624 p. (in Russ.).

Received December 23, 2014

Revised April 27, 2015 
